\title{
Clostridium difficile Measurement
}

National Cancer Institute

\section{Source}

National Cancer Institute. Clostridium difficile Measurement. NCI Thesaurus. Code C150637.

The determination of the amount of Clostridium difficile species in a biological sample. 